\title{
SELECTION ACTING UPON SLOW-MIGRATING ADH ALLELES DIFFERING IN ENZYME ACTIVITY
}

\author{
JAMES N. THOMPSON, Jr. and TIMOTHY N. KAISER \\ Department of Zoology, 730 Van Vleet Oval, Norman, Oklahoma, 73019
}

Received 2.ix.76

\begin{abstract}
Summary
Relative egg to adult viability was compared in three stocks of Drosophila melanogaster differing in alcohol dchydrogenase (ADH) activity. Two of these, Grell's standard $\mathrm{ADH}^{\mathrm{s}}$ and a mutant $\mathrm{ADH}^{\mathrm{S}}$ strain producing half the normal number of $\mathrm{ADH}$ molecules, had the same electrophoretic mobility. The experiment demonstrated a correlation between survival in alcohol-supplemented media and enzyme activity. This supports the hypothesis that enzyme activity per se, rather than some other attribute of allelic differences, may be responsible for the previously observed selective advantage of high activity alleles on alcohol media.
\end{abstract}

\section{Introduction}

Much attention has been given to studies of the levels and evolutionary consequences of natural genetic variation. Having started as a rather rigid selectionist versus neutralist controversy, the question has itself evolved to one of explaining what proportion of natural genetic variation can be attributed, at a particular time (Thoday, 1975), to selective forces and what proportion is effectively neutral (Kimura and Ohta, 1971; Lewontin, 1974).

Polymorphisms involving electrophoretic variants of the enzyme alcohol dehydrogenase $(\mathrm{ADH})$ are common in Drosophila, and factors maintaining or influencing these polymorphisms have been studied by a number of workers (Gibson, 1970; Day, et al., 1974; Briscoe, et al., 1975; Morgan, 1975; McDonald and Avise, 1976; Oakeshott, 1976; and others). The fastmigrating allele $\left(\mathrm{ADH}^{\mathrm{F}}\right)$, which also has a higher enzyme activity, appears to have a selective advantage in high environmental concentrations of certain alcohols, compared with the slow-migrating allele (ADHs) which has a selective advantage at high temperatures (Vigue and Johnson, 1973) and in the presence of some alcohols (such as penten-3-ol, which is converted into a toxic ketone, Sofer and Hatkoff, 1972). The maintenance of natural polymorphisms can be pictured as a composite of such interactions.

There are, however, at least two obvious difficulties with designing studies of selection influencing electrophoretic (or any other) variants. One difficulty is that in many instances, we do not yet have a clear idea of the normal function of the enzyme. This makes it difficult to propose convincing causal relationships between gene frequencies and environmental variables. Indeed, it is now clear that electrophoretic variant classes may themselves be heterogeneous collections, differing, for example, in thermal stability (Bernstein et al., 1973), but which happen to have the same rate of migration on a gel. Generalisations from such heterogeneous collections are necessarily difficult. The second problem is that often one 
can not eliminate the possibility that the selective factor is acting upon some unmarked locus linked to the variant being studied.

Although these two difficulties have been resolved to a significant extent in the work on alcohol dehydrogenase, an interesting ADH mutant has recently allowed us to attempt to confirm the evidence of selective effects of alcohol, using alleles that are identical in electrophoretic mobility, but that differ in enzyme activity.

The hypothesis supported by the work of Morgan (1975) and others is that electrophoretically detectable ADH variants are not neutral to applied selection pressures. Lowered $\mathrm{ADH}$ activity levels cause $\mathrm{ADH}^{\mathrm{S}}$ individuals to break down harmful alcohols less efficiently and, thus, have a reduced survival rate in alcohol-supplemented media. This hypothesis implies that an $\mathrm{ADH}^{\mathrm{S}}$ line with even lower than normal $\mathrm{ADH}^{\mathrm{S}}$ activity would have a correspondingly lower survival rate. This prediction assumes that the reaction to alcohol levels is due solely to the observed activity differences rather than to some other property of the $\mathrm{ADH}^{\mathrm{S}}$ enzyme, although the underlying relationship between viability and enzyme activity may not lead to a direct correlation between the two. We have been able to test this prediction using an $\mathrm{ADH}^{\mathrm{S}}$ line, isolated from a natural population of Drosophila melanogaster, which produces only half as many $\mathrm{ADH}$ molecules as the typical $\mathrm{ADH}^{\mathrm{s}}$ allele. As far as we have been able to discover, the $\mathrm{ADH}^{\mathrm{s}}$ alleles are otherwise essentially identical.

\section{Materials and methods}

Relative egg to adult viability was tested on a variety of alcoholsupplemented media. Three stocks of Drosophila melanogaster were used: $\mathrm{ADH}^{\mathrm{F}}$ and $\mathrm{ADH}^{\mathrm{s}}$ from Cambridge University, obtained originally from E. H. Grell, and a homozygous $\mathrm{ADH}^{\mathrm{s}}$ stock which was derived from a vein mutant selection line after outcrossing to a wild type stock collected near Cambridge, England (ve Short selection line, see Thompson, 1974). After many generations of selection for vein phenotype, the stock was found, by Mr Peter Young at Cambridge, to have very low ADH activity on an isopropanol substrate. Later tests, however, showed no causal relationship betwcen the vein phenotype and the ADH activity, which was presumably polymorphic in the original population. This stock is referred to here as $\mathrm{ADH}^{\mathrm{s}}(\mathrm{ve})$.

$\mathrm{ADH}$ activity was measured using standard assays similar to those described by Ward and Hcbert (1972). For each assay $40 \mathrm{mg}$ of young adult $D$. melanogaster were homogenised in $1 \mathrm{ml}$ of distilled water, centrifugcd, and the supernatant placed in an ice bath. Enzyme activity was measured in a spectrophotometcr at $25^{\circ} \mathrm{C}$ using $0.1 \mathrm{ml}$ of the supernatant, $2.4 \mathrm{ml}$ of phosphate buffer containing NAD, and $0.03 \mathrm{ml}$ of isopropanol or other alcohol as a substrate.

The veinlet Low activity line was found to have ADH activity that was approximately half that of the normal $\mathrm{ADH}^{s}$ stock. Taking $\mathrm{ADH}^{\mathrm{F}}$ as a standard with relative activity of 1.0 we found the ratio of activities on isopropanol of $\mathrm{ADH}^{\mathrm{F}}$ to $\mathrm{ADH}^{\mathrm{S}}$ to $\mathrm{ADH}^{\mathrm{S}}(\mathrm{ve})$ to be approximately $1 \cdot 0: 0 \cdot 57: 0 \cdot 28$.

By radial immunodiffusion, we found that the unusually low activity could be accounted for by the fact that this stock produces approximately 

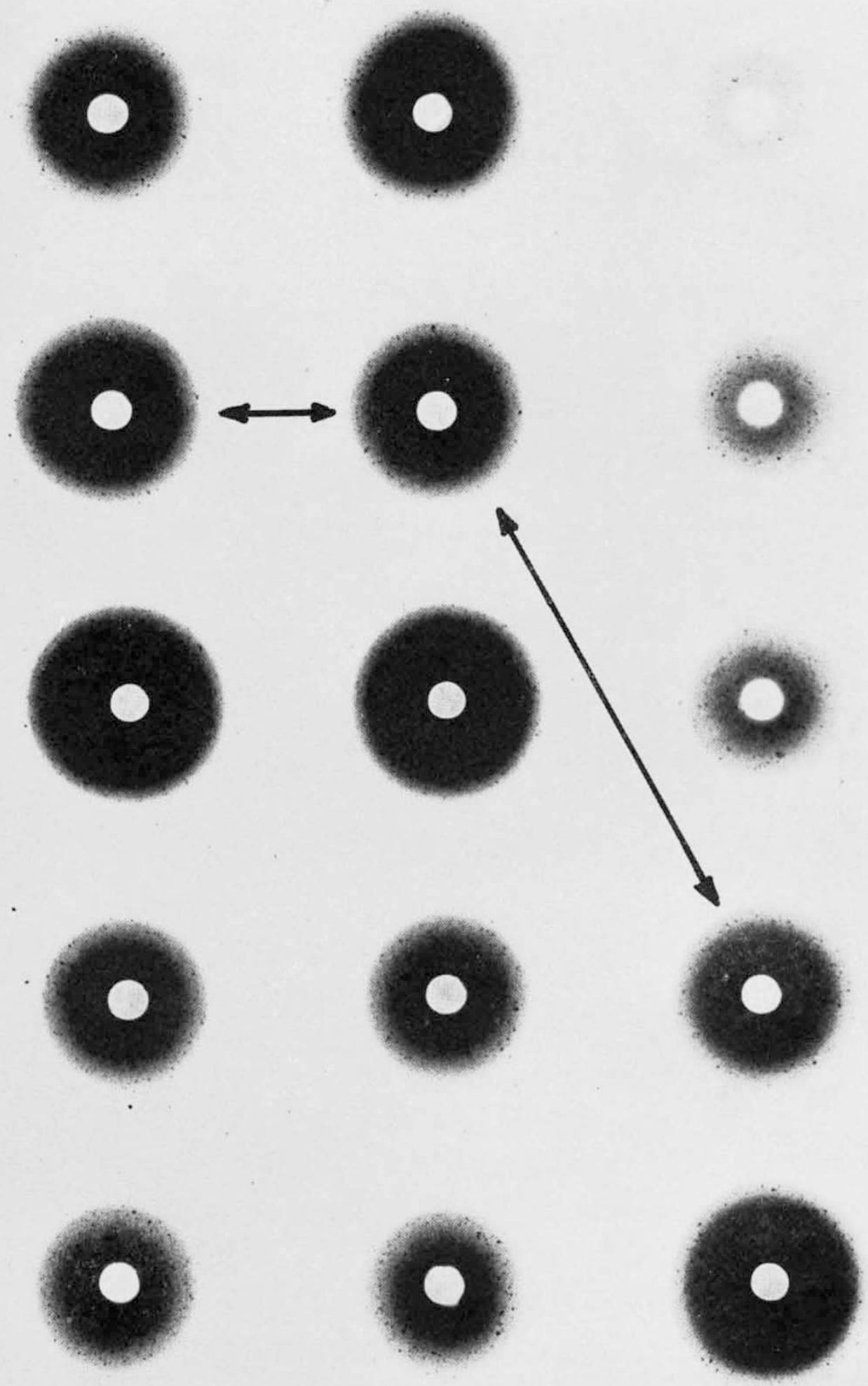

Radial immunodiffusion plate of extracts from Drosophila melanogaster cultures, run on anti-ADHs. Control dilutions of Grell's standard $\mathrm{ADH}^{\mathrm{S}}$ are shown at the right; from the bottom, 100, 50,25, 12.5 and 6.25 per cent. The two left columns are replicate assays of various ADH stocks as described in the text. The important comparison, $\mathrm{ADH}^{\mathrm{S}}(\mathrm{ve})$ with the 50 per cent dilution of standard $\mathrm{ADH}^{\mathrm{S}}$ is noted with arrows. 
half as many $\mathrm{ADH}$ molecules as the normal $\mathrm{ADH}^{\mathrm{S}}$ stock. We are grateful to Nigel Lewis, Cambridge University, who helped carry out this assay.

The radial immunodiffusion assay followed the technique of Rasanen (1974) and is illustrated in plate I. Standard dilutions of Grell's ADHS stock are shown at the right and replicate assays of five $\mathrm{ADH}$ lines are shown at the left. The assay lines are, from bottom to top, Df64j/ADHS, $\mathrm{Df} 64 \mathrm{j} / \mathrm{ADH}^{\mathrm{S}}$; ve/ $+, \mathrm{ADH}^{\mathrm{F}}, \mathrm{ADH}^{\mathrm{S}}$; ve $\left(=\mathrm{ADH}^{\mathrm{S}}(\mathrm{ve})\right), \mathrm{ADH}^{\mathrm{3}}{ }^{3}$ (25 per cent dilution). See Lindsley and Grell (1967) for descriptions. Careful measurements of the size of the disk from $\mathrm{ADH}^{\mathrm{S}}(\mathrm{ve})$ confirmed that only half as many $\mathrm{ADH}$ molecules were being produced by flies homozygous for $\mathrm{ADH}^{\mathrm{S}}$ from the veinlet selection line.

Relative egg to adult viability was measured by the survival from 50 eggs in each tube of an experimental run. Adults of each genotype were allowed to lay eggs on a yeast, agar, and dextrose medium in plastic sandwich boxes for 18 to 20 hours. A potato flake and dextrose medium was used in the experimental and control tubes, because alcohol is not miscible in the agar-base media normally employed in culture maintenance. Tubes were supplemented with $0.1 \mathrm{ml}$ of 95 per cent ethanol, $0.05 \mathrm{ml}$ of N-butanol, or had no supplement (control). Fifty eggs were taken at random from the egg-laying boxes and placed in each tube. Adults were counted as they eclosed over a period not exceeding 17 days from the initiation of each replicate. Two tubes of each type were set up at the same time, one tube having been made by each of us ("scorer" factor in table 3 ). The set of 18 experimental and control tubes was replicated eight times over a period of several months (" replicate" factor in table 3).

\section{Results AND Discussion}

Assays of enzyme activity of $\mathrm{ADH}^{\mathrm{F}}, \mathrm{ADH}^{\mathrm{S}}$, and $\mathrm{ADH}^{\mathrm{S}}$ (ve) confirmed that the $\mathrm{ADH}^{\mathrm{S}}$ (ve) line had consistently lower activity than the $\mathrm{ADH}^{\mathrm{S}}$ standard. The results of these assays are summarised in table 1 , and show

TABle 1

Relative activity of $A D H^{F}, A D H^{S}$ and $A D H^{S}$ (ve) enzymes measured on four substrate alcohols. $A D H^{F}$ is given a relative activity of 1.0 and is used as a standard in each comparison

\begin{tabular}{lccc}
\multicolumn{1}{c}{ Alcohol } & $\mathrm{ADH}^{\mathrm{F}}$ & $\mathrm{ADH}^{\mathrm{S}}$ & $\mathrm{ADH}^{\mathrm{S}}(\mathrm{ve})$ \\
Ethanol & $1 \cdot 0$ & $0 \cdot 443$ & $0 \cdot 217$ \\
N-butanol & $1 \cdot 0$ & $0 \cdot 554$ & $0 \cdot 304$ \\
Isopropanol & $1 \cdot 0$ & $0 \cdot 439$ & $0 \cdot 230$ \\
Cyclohexanol & $1 \cdot 0$ & $0 \cdot 651$ & $0 \cdot 436$
\end{tabular}

that the $\mathrm{ADH}^{\mathrm{S}}$ (ve) line typically has about half the activity of the standard $\mathrm{ADH}^{\mathrm{S}}$ on a variety of substrate alcohols. This difference can be explained by the fact that $\mathrm{ADH}^{\mathrm{S}}$ (ve) produces approximately half as many $\mathrm{ADH}$ molecules as the standard line. The factor which causes this decrease in production can be separated from the structural locus by recombination (Ashburner, Thompson and Woodruff, unpublished), and the ADH enzyme locus itself does not appear to differ from the $\mathrm{ADH}^{\mathrm{S}}$ locus in standard Grell lines.

The various genotypes showed significant differences in enzyme activity 38/2-E 
on both ethanol and N-butanol, which confirms the observations of Morgan (1975) and others. These two alcohols were, therefore, chosen to compare relative viabilities of the three genotypes.

Emerging adults were counted from 50 eggs placcd in each experimental or control tube. The total number of adults from eight separate replicates ( $N=400$ eggs for each treatment in pooled replicates) is shown in table 2 and the raw data are analysed in table 3 . It is clear that the mean viability

\section{TABLe 2}

Summary of the number of adults eclosing from eight pooled experimental replicates $(\mathcal{N}=400$ eggs $)$. Control is not supplemented with alcohol. Viability is shown as a percentage of viability on respective controls in the parentheses

Treatment

Ciontrol

Ethanol

N-butanol

\section{$\mathrm{ADH}^{\mathrm{F}}$}

357

$347(92 \cdot 7 \%)$

$\mathrm{ADH}^{\mathrm{S}}(\mathrm{ve}) \dagger$
493
$275(55.8 \%)$
$62(12.6 \%)$

* Using a test of the equality of percentages (R. R. Sokal and F. J. Rohlf, 1969, Biometry, Freeman, San Francisco), it was shown that relative viability of ADHs on both ethanol and N-butanol was significantly lower than that of $\mathrm{ADH}^{\mathrm{F}}(\mathrm{P}<0.001)$.

$\dagger$ Relative viability of $\mathrm{ADH}^{\mathrm{S}}(\mathrm{ve})$ significantly lower on ethanol $(\mathrm{P}<0 \cdot 05)$ and on N-butanol $(\mathrm{P}<0 \cdot 001)$.

\section{TABLE 3}

Analysis of variance of the results in table 2. See the text for discussion. (Non-significant interactions have been pooled and used as the error term)

\begin{tabular}{|c|c|c|c|c|c|}
\hline Factor & d.f. & S.S. & M.S. & $\mathrm{F}$ & $\mathrm{P}$ \\
\hline Alcohol (A) & 2 & $6729 \cdot 639$ & $3364 \cdot 820$ & $83 \cdot 5$ & $<0.001$ \\
\hline Scorer $(\mathrm{S})$ & 1 & $80 \cdot 999$ & $80 \cdot 999$ & $2 \cdot 0$ & n.s. \\
\hline Genotype (G) & 2 & $186 \cdot 888$ & $93 \cdot 444$ & $2 \cdot 3$ & n.s. \\
\hline Replicate (R) & 7 & $5041 \cdot 414$ & $720 \cdot 202$ & $17 \cdot 9$ & $<0.001$ \\
\hline$A \times G$ & 4 & $1655 \cdot 734$ & $413 \cdot 934$ & $10 \cdot 3$ & $<0.001$ \\
\hline$G \times R$ & 14 & $1244 \cdot 827$ & 88.916 & $2 \cdot 2$ & $0.05>\mathrm{P}>0.01$ \\
\hline $\begin{array}{l}\text { Other interactions (pooled } \\
\text { error term) }\end{array}$ & 113 & $4555 \cdot 138$ & $40 \cdot 311$ & & \\
\hline Total & 143 & $19494 \cdot 639$ & & & \\
\hline
\end{tabular}

in control cultures varies widely between genotypes, $\mathrm{ADH}^{\mathrm{s}}(\mathrm{ve})$ having the highest viability in control cultures. There is, however, no significant difference between tubes set up at the same time by different people, allowing the data from sets of tubes with identical alcohol treatments to be pooled. There are significant differences among replicates (table 3), though this is hardly surprising. Thus, mean viabilitics have been expressed as a function of the control mean in table 2.

One source of confusion when cxamining these data is that the $\mathrm{ADH}^{\mathrm{s}}$ (ve) line has the highest viability on control cultures, but the greatest decrease in relative viability on alcohol media. Thus, the effect on alcohols is lost if it is not remembered that the high normal viability and the alcohol treatment are cancelling each other, relative to the other genotype reactions. For this reason, the "genotype" factor in the analysis of variance is not significant. The effect of alcohol treatment should be clear from table 2, 
however. Another interesting observation is the highly significant alcohol times genotype interaction term $(\mathrm{A} \times \mathrm{G}$ interaction, table 3$)$. This means that the different alcohols have different effects upon viability. Apparently the correlation between relative viability and enzyme activity is not a direct correlation. For the purposes of explaining selective maintenance of enzyme alleles, however, the important point is that higher activity is consistently associated with higher relative viability.

Using lines having similar electrophoretic mobilities we have, therefore, been able to confirm that the relative viability differences are a function of the observed differences in enzyme activity, rather than being a function of some other characteristic differentiating $\mathrm{ADH}^{\mathrm{S}}$ alleles. A number of other interesting questions can be asked using these lines, including the isolation and characterisation of the factor producing the reduction in molecule formation, and these are now in progress.

Acknowledgments.-We are grateful to Dr Jenna Hellack for helpful cornments on the manuscript. This work was done with the support of a Faculty Research Grant from the University of Oklahoma and DHEW-NIH grant ES-1439-01.

\section{RefERENCES}

BERnstein, s. C., throckmorton, L. H., AND hUBBy, J. L. 1973. Still more genetic variability in natural populations. Proc. Nat. Acad. Sci.. U.S.A., 70, 3928-3931.

BRiscoe, D. A., ROBERTSON, A., AND malpicA, J. M. 1975. Dominance at Adh locus in response of adult Drosophila melanogaster to environmental alcohol. Nature, 255, 148-149.

DAY, T. H., HILliER, P. C., AND ClARKE, B. 1974. Properties of genetically polymorphic isozymes of alcohol dehydrogenase in Drosophila melanogaster. Biochem. Genet., 11 , 141-153.

GrBson, J. 1970. Enzyme flexibility in Drosophila melanogaster. Nature, 227, 959-960.

kimura, m., ANd ohta, т. 1971. Theoretical Aspects of Population Genetics. Princeton Univ. Press, Princeton, N.J.

Lewontin, R. c. 1974. The Genetic Basis of Evolutionary Change. Columbia Univ. Press, New York.

LINDSLEY, D. L., AND GRELL, E. H. 1967. Genetic Variations of Drosophila melanogaster. Carnegie Institution of Washington, Publication 627.

MCDONALD, J. F., AND AVISE, J. C. 1976. Evidence for the adaptive significance of enzyme activity levels: Interspecific variation in $\alpha-\mathrm{GPDH}$ and Adh in Drosophila. Biochem. Genet., 14, 347-355.

MORGAN, P. 1975. Selection acting directly on an enzyme polymorphism. Heredity, 34, 124-127.

oAkeshotт, J. G. 1976. Selection at the alcohol dehydrogenase locus in Drosophila melanogaster imposed by environmental ethanol. Genet. Res., Camb., 26, 265-274.

RASANEN, J. A. 1974. The calculation of antigen concentrations in the single radial immunodiffusion. Immunochemistry, 11, 519-520.

SOFER, W. H., AND HATKOFF, M. A. 1972. Chemical selection of alcohol dehydrogenase negative mutants in Drosophila. Genetics, 72, 545-549.

тHODAY, J. м. 1975. Non-Darwinian "evolution" and biological progress. Nature, $255,675-677$.

THOMPson, J. N., JR. 1974. Studies on the nature and function of polygenic loci in Drosophila. I. Comparison of genomes from selection lines. Heredity, 33, 373-387.

VIGUE, C. L., AND JOHNSON, F. M. 1973. Isozyme variability in species of the genus Drosophila. VI. Frequency-property-environment relationships of allelic alcohol dehydrogenases in Drosophila melanogaster. Biochem. Genet., 9, 213-227.

WARD, R. D., AND HEBERT, P. D. N. 1972. Variability of alcohol dehydrogenase activity in a natural population of Drosophila melanogaster. Nature Netw Biol., 236, 243-244. 